\title{
An association between change in types of roads and cultivated farm area at Agriculture Sector
}

\author{
Elena Kozlova ${ }^{1}$, Muhammad Imtiaz Subhani ${ }^{2}$, Fatima Ulbasheva ${ }^{3}$, and Denis Ushakov ${ }^{4, *}$ \\ ${ }^{1}$ Rostov State Transport University, Rostov-on-Don, Russia \\ ${ }^{2}$ ILMA University, Karachi, Pakistan \\ ${ }^{3}$ Moscow State University, Moscow, Russia \\ ${ }^{4}$ Suan Sunandha Rajabhat University, Bangkok, Thailand
}

\begin{abstract}
This study investigates the association between change in types of roads and cultivated farm area at Agriculture Sector. Time series data was used to interrogate the proposition of this paper. The time series annual data from 2000 to 2020 was collected from the Eikon data stream on variables which include change in high type roads \& change in low type roads around the farm area and cultivated farm area from of the 12 rural zones of provinces of Sind, Punjab and KPK of Pakistan. Findings confirmed that there is a significant association between increases in low type of roads and cultivates farm area of all selected rural zones of outlined provinces. While there is no significant relationship between the high type roads and the farm area and the cultivated area of stated 12 zones of outlined provinces findings further revealed.
\end{abstract}

\section{Introduction}

Agriculture is the hub of economic activity in Pakistan. It is the basic for economic development and growth of the economy. It directly contributes to gross domestic product and provide employment to the total labor force of the country. Major part of population depends earning of agriculture in many ways, therefore development of agriculture is development of country. The agriculture sector strong linkages with the rest of the economy are not fully captured in the statistics. While on the other hand, the sector is a primary supplier of raw materials to downstream industry, contributing substantially to Pakistan's exports, on the other, it is a large market for industrial products such as fertilizer, pesticides, tractors and agricultural implements. The continous improvement and rehabilization of the existing roads reflects the government's enhanced focus on infrastructure. As a result of an emphasis on high type of roads many low type of roads were converted to high type $[1,2]$.

They are many ways of improving these roads network [3]. Changes in restructuring are connected to make changes and development in reforms. There are weak human rights for those who are demotivated and depart from land farming [4].

\footnotetext{
*Corresponding author: denis.us@ssru.ac.th
} 
Research has been shown in past that how if there are strong developments in roads which are connected to agriculture land may create an effective change at agriculture land. Basically transportation to agriculture land is done through the development of the infrastructure of roads. In the areas benefiting from the road upgrading, the land is more productive, and the volume and value of agricultural produce is higher. As it became easier to ship produce quickly without damaging it, farmers shifted from low to high type [5].

An association between infrastructure and reforms at agriculture sector has a relation and it effect the performance overall. Reforms are taken place at every sector to make the development and changes. Research has shown uptil now that agriculture sector has made many changes and development. In this research, study measured Infrastructure development through low type of and high type of roads and reforms through agriculture development at agriculture land. Infrastructure is connected with reforms of agriculture land. Basically research focused on the difference between cultivated, uncultivated, forest, tenant's cultivated waste area cultivated area which show positive result which means that's there is difference and it's not cover by another area.

\section{Literature Review}

As the economic policies guide the development process for every country and the agricultural sector is, thus, affected by the infrastructure and land reforms (Stone, 1998). In developed countries, these reforms mainly sought to improve industry performance by introducing competition in some selected segments and redesigning the regulatory and legal framework so as to enhance diversification and quality of service, pricing and efficiency although based on the same essential principles these reforms faced a significantly different context in the developing countries and these countries were typically characterized by not only poor infrastructures and weak economic conditions but also severely inadequate administrative rules [5].

There are two streams of literature available about the determinants of regulatory performance in infrastructure industries in which first stream is about empirical emphasizes on the impact of regulatory governance on performance [6,7]. The second stream, that is conceptual argues that when investigating regulatory performance in infrastructure sectors the relevant game to consider takes place upstream at the higher level of politics [8].

Therefore, the market reform is not only accustomed by divisional factors, but also by institutional and macroeconomic factors affecting the efficiency of institutional rules such as the corruption engrained in the political system, and the financial situation often constrained in developing countries [9].

These constraints consist of high debt services and inefficient taxation. The impact of the divisional reforms on the deployment of infrastructure and the conditions leads to specific reforms and that allow them to propagate [5]. This is the case for macroeconomic reforms during the 1980s and for structural reforms during the entire period [10]. There is a low impact of some economic reforms. This is the case when structural reforms are implemented in a volatile macroeconomic environment, and when macroeconomic reforms are implemented without a sufficient level of structural reforms [11]. The literature available on the infrastructure and reforms in the agriculture sector is based upon the transitional economies and the developing economies of the world [12].

Successful modern economies are characterized by diversity, heterogeneity, and the pursuit of comparative advantage and they allow individuals and firms to pursue favorable trading and agriculture possibilities. Institutions that were once functional in organizing society were no longer appropriate in a world of diversity and heterogeneity and Institutions that induce efficient responses to unique situations and unique people produce the greatest value in the new economy [13]. 
Legal frameworks that impose regulation and rigidity destroy the incentive of participants in unique employment and production decisions to foster and use the knowledge which is the slow implementation of legal reforms limits the ability of agents to contract, and the lack of contract enforcement by state and local authorities makes it very difficult to attract investors Mexican law is not clear on what arrangements should be considered informal [12]. Considering the slow-moving Mexican economy and the reasons for its poor performance are low oil, many public institutions are weak and the level of infrastructure is low $[5,14,15]$.

Agricultural production and incomes in both countries soared immediately after the initial reforms with seventy percent of the labor force employed in agriculture and the major share of consumer income spent on food, the reforms had a major positive impact on the reduction of poverty and the rise of well-being of the population in rural China [14].

Agricultural productivity also grew in a sustained way throughout the entire reform period [5] and most researchers concur that the growth of the sector contributed importantly to overall performance $[13,16]$.

There is some improvement in developing economies which can be seen from the efforts of these countries in the areas of economic reforms, human capital, and physical infrastructure $[16,17]$. By promoting deregulation of domestic industry, liberalizing rules for foreign investment, and reducing tariff and non tariff barriers on imports, the authorities engaged deliberately on an outward looking development strategy, in which strengthening of export capacity is called upon to play a dominant role [4].

Table 1. Correlation analyzis results.

\begin{tabular}{|c|c|c|c|c|}
\hline & & $\begin{array}{l}\text { \% Change in } \\
\text { High Type } \\
\text { Roads } \\
\text { Construction } \\
\end{array}$ & $\begin{array}{l}\text { \% Change in } \\
\text { Low Type } \\
\text { Roads } \\
\text { Construction } \\
\end{array}$ & $\begin{array}{c}\text { Cultivated } \\
\text { Area }\end{array}$ \\
\hline \multirow{3}{*}{$\begin{array}{l}\text { \% Change in } \\
\text { High Type } \\
\text { Roads } \\
\text { Construction }\end{array}$} & $\begin{array}{l}\text { Pearson } \\
\text { Correlation }\end{array}$ & 1 & .546 & .406 \\
\hline & Sig. (2-Tailed) & & 053 & .168 \\
\hline & $\mathrm{N}$ & 13 & 13 & 13 \\
\hline \multirow{3}{*}{$\begin{array}{l}\text { \% Change in } \\
\text { Low Type } \\
\text { Roads } \\
\text { Construction }\end{array}$} & $\begin{array}{l}\text { Pearson } \\
\text { Correlation }\end{array}$ & .546 & 1 & $.605^{*}$ \\
\hline & Sig. (2-Tailed) & .053 & & .028 \\
\hline & $\mathrm{N}$ & 13 & 13 & 13 \\
\hline \multirow{3}{*}{$\begin{array}{l}\text { Cultivated } \\
\text { Area }\end{array}$} & $\begin{array}{l}\text { Pearson } \\
\text { Correlation }\end{array}$ & .406 & $.605^{*}$ & 1 \\
\hline & Sig. (2-Tailed) & .168 & .028 & \\
\hline & $\mathrm{N}$ & 13 & 13 & 13 \\
\hline
\end{tabular}

\section{Research Method}

Time series data was used to interrogate the proposition of this paper. The time series annual data from 2000 to 2020 was collected from the Eikon data stream on variables which include change in high type roads \& change in low type roads around the farm area and cultivated farm areas from of the 12 rural zones of provinces of Sind, Punjab and KPK of Pakistan. Further, Pearson correlation test was deployed to evaluate the possible associations of the change in high type roads \& change in low type roads around the farm area with cultivated farm areas. 


\section{Findings \& Results}

Findings of this paper reveals that there is a significant association between increases in low type of roads and cultivates farm area as Coefcient of correlation between these two are found 0.605 at $\mathrm{P}<0.05$. This empirical results explains that if there is one percent positive increase in low type roads around the farm area then the cultivated area will get increased 0.605 percent significantly. Findings further confirms that there is no significant relationship between the high types road around the farm area and the cultivated area as coefficient of correlation are found insignificant i.e. $\mathrm{r}=0.406$ at $\mathrm{P}>0.05$.

\section{Discussion \& Conclusion}

This paper concludes that there is a significant association between increases in low type of roads and cultivates farm area of all selected rural zones of outlined provinces. While there is no relationship between the high type roads and the farm area and the cultivated area of stated 12 zones of outlined provinces. These findings imply that the cultivated farm area or the cultivations on agricultural farm area of relies the most on low type roads and the positive change in low type roads around it rather than the high types roads or an increase in high type roads.

\section{References}

1. A. Estache et al., Journal of economics 35, 1-27 (2005)

2. D. Ushakov et al., IOP Conference Series: Earth and Environmental Science 272(3) (2019)

3. A. Trzeciak, European Review of Agricultural Economics 26(3), 283-304 (1999)

4. S. Fan, G. Pardey, Journal of Development Economics 53, 115-137 (1997)

5. J. Huang, Journal of Development Economics 49, 337-369 (1996)

6. J. Cubbin, C. Stern, Regulatory effectiveness: The impact of regulation and regulatory governance arrangements on electricity industry outcomes (World Bank Policy Research Working Paper, 2005)

7. D. Ushakov et. Al, IOP Conference Series: Earth and Environmental Science 422(1), 012128, (2020)

8. P.T. Spiller, B. Tommasi, Handbook of Telecommunications Economics 2, 34-54 (2003)

9. N. Sicular, The China Quarterly 144, 1020-1046 (1995)

10. S. Rozelle, J. Swinnen, Journal of economics 21, 28-73 (2000)

11. P.L. Pingali, V.T. Xuan, Economic Development and Cultural Change 40(4), 697-718 (1992)

12. V. Blinova et al, Economic Policy and Unemployment in Russia's Regions 1-12 (2007)

13. D. Perkins, Journal of Economic Perspectives 34, 23-46 (1994)

14. J. Lin, American Economic Review 82(1), 34-51 (1992)

15. J. McMillan, I. Zhu, Journal of Political Economy 97(4), 781-807 (1989)

16. J. Huang et al., The Creation and Spread of Technology (American Association for the Advancement of Sciences, Washington, 2000)

17. B. Stone, The China Quarterly 153, 163-189 (1998) 